\title{
Perancangan Ulang User Interface Mesin Parkir Meter Jakarta
}

\author{
Maya Arlini Puspasari ${ }^{1}$, Triasni M. L. Sibarani², Erlinda Muslim ${ }^{3}$, Boy Nurtjahyo Moch. ${ }^{4}$ \\ ${ }^{1,2,3,4)}$ Fakultas Teknik, Departemen Teknik Industri, Universitas Indonesia \\ Depok, Jawa Barat, 16424 \\ Email: maya.arlini@yahoo.com, triasni ti2011@yahoo.com, erlinda@eng.ui.ac.id, boymoch@eng.ui.ac.id
}

\begin{abstract}
ABSTRAK
Parkir Meter adalah salah satu alternatif pemerintah DKI Jakarta untuk memperbaiki manajemen parkir. Namun masih ditemui sejumlah masalah usability dalam penggunaan mesin sehingga menyebabkan ketidakpuasan pengguna. Masalah usability berkaitan erat dengan user interface karena user interface adalah bagian paling penting pada mesin yang bisa dilihat dan disentuh oleh pengguna. Penelitian ini dilakukan untuk mengevaluasi dan melakukan perancangan ulang user interface mesin parkir meter Jakarta. Metode yang digunakan untuk mengevaluasi adalah dengan metode usability testing. Hasil yang didapat dari penelitian ini adalah tingkat usability mesin parkir meter masih sangat rendah dan hasil perancangan ulang user interface terbukti lebih efektif, efisien dan meningkatkan kepuasan pengguna.
\end{abstract}

Kata kunci: mesin parkir meter, retrospective think aloud usability, usability testing, user interface

\section{Pendahuluan}

Parkir adalah keadaan tidak bergerak suatu kendaraan yang bersifat tidak sementara [1]. Setiap kendaraan bermotor yang berlalu lalang di jalan membutuhkan ruang untuk parkir. Seiring dengan peningkatan jumlah kendaraan di Provinsi DKI Jakarta, maka problematika pengelolaan atau penyelenggaraan perparkiran juga semakin kompleks. Problematika ini semakin memburuk dikarenakan manajemen parkir Kota Jakarta yang belum efektif bahkan cenderung buruk. Permasalahan pengelolaan perparkiran di Provinsi DKI Jakarta terkait dengan berbagai aspek, salah satunya aspek Keuangan (Pendapatan Daerah) melalui retribusi parkir [2]. Dinas Perhubungan DKI Jakarta mulai melaksanakan berbagai upaya untuk memperbaiki manajemen parkir diantaranya dengan mencari teknologi untuk sistem pengendalian pemungutan retribusi parkir dengan sistem terintegrasi untuk melaksanakan pemungutan retribusi yang efektif. Salah satu langkah pemerintah DKI Jakarta adalah pengadaan Parkir Meter yang sudah melewati tahap uji coba di Jalan Sabang atau Jalan Agus Salim, Jakarta Pusat. Gambar mesin parkir meter dapat dilihat pada gambar 1 dibawah ini.

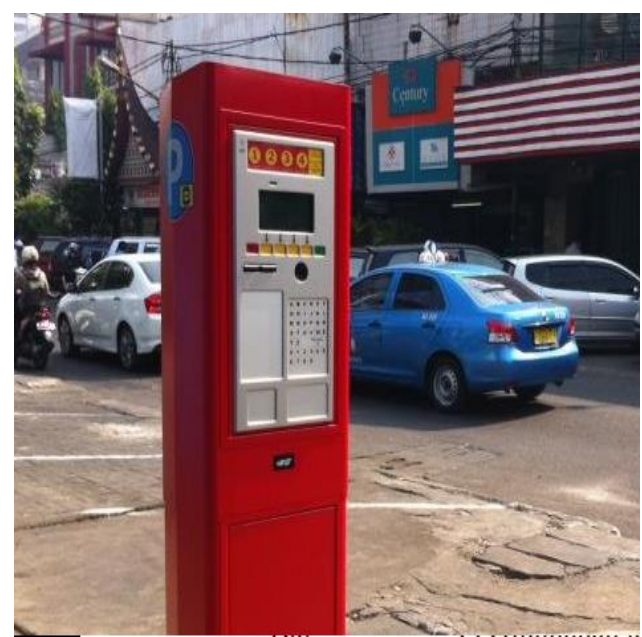

Gambar 1. Mesin Parkir Meter di DKI Jakarta

Namun pemakaian mesin parkir meter ini masih dirasakan belum memuaskan. Penelitian awal menunjukkan hasil bahwa 75\% dari responden yang diminta untuk mengisi kuesioner merasa belum puas saat menggunakan mesin parkir meter ini. Setelah dilakukan time study, rata - rata seorang responden yang sudah pernah menggunakan mesin ini membutuhkan total waktu selama 90 detik untuk melakukan transaksi dengan mesin, bahkan responden yang baru pertama kali menggunakan mesin membutuhkan total waktu hingga 170 detik untuk melakukan transaksi. Para pengguna mesin masih merasakan kesulitan dalam menggunakan mesin parkir meter.

Kesulitan dan kepuasan pengguna dalam menggunakan mesin merupakan bagian dari usability mesin dan dalam penggunaan mesin parkir meter ini belum pernah diadakan pengukuran usability mesin. Usability sangat berkaitan dengan user interface. 
[3]. Dengan kata lain, usability terutama berdampak pada user interface dan bukan inti dari sistem. Ketergunaan mesin dapat dilihat melalui user interface-nya, dimana desain user interface memiliki pengaruh besar terhadap ketergunaan mesin [4]. User interface adalah bagian paling penting pada setiap sistem komputer atau mesin karena bagian ini adalah bagian yang memiliki interaksi paling besar dengan pengguna. Bagian user interface merupakan bagian dari komputer atau mesin yang dapat dilihat, bisa didengar, dan dapat disentuh. Tujuan dari desain user interface yang sederhana adalah untuk memberi kemudahan kepada pengguna sehingga interaksi yang ada menjadi produktif dan menyenangkan [5].

Dengan adanya kebutuhan untuk meningkatkan usability mesin parkir meter Jakarta maka diperlukan suatu studi atau penelitian untuk merancang ulang user interface pada mesin parkir meter Jakarta. Tujuan dari penelitian ini adalah untuk mengetahui tingkat usability dan mengetahui masalah - masalah yang ada pada user interface mesin parkir meter Jakarta dengan menggunakan metode Retrospective Think Aloud, System Usability Scale, Performance Measurement, dan Questionnaire for User interface Satisfaction. Tujuan lainnya yang ingin dicapai dari penelitian ini adalah melakukan perancangan ulang user interface mesin parkir Jakarta untuk memudahkan pengguna dalam melakukan transaksi dengan mesin dan meningkatkan kepuasan pengguna.

\section{Metode Penelitian}

Pada penelitian ini, ada 2 langkah utama yang akan dilakukan yaitu mengukur usability mesin parkir meter dengan menggunakan kuesioner awal, metode performance measurement (memberikan 3 tugas kepada responden), metode retrospective think aloud, kuesioner SUS, kuesioner QUIS dan kuesioner tambahan. Dan langkah selanjutnya adalah melakukan perancangan ulang user interface berdasarkan hasil pengolahan data sebelumnya. Verifikasi akan dilakukan untuk menguji pilihan desain user interface yang dipilih berdasarkan kuesioner preferensi subjektif.

Pada langkah usability testing responden yang terlibat adalah responden kelompok mahir sebanyak 6 orang yang terdiri dari juru parkir dan admin mesin dan responden kelompok pemula sebanyak 13 orang yang terdiri dari responden yang belum pernah menggunakan mesin parkir meter sebelumnya. Pengambilan data usability testing dilakukan di Jalan Sabang, Jakarta Pusat pada pukul 11.00 WIB - 14.00 WIB (peak hour). Langkah - langkah dalam pengambilan data usability testing dapat dilihat pada gambar 2 dibawah ini.

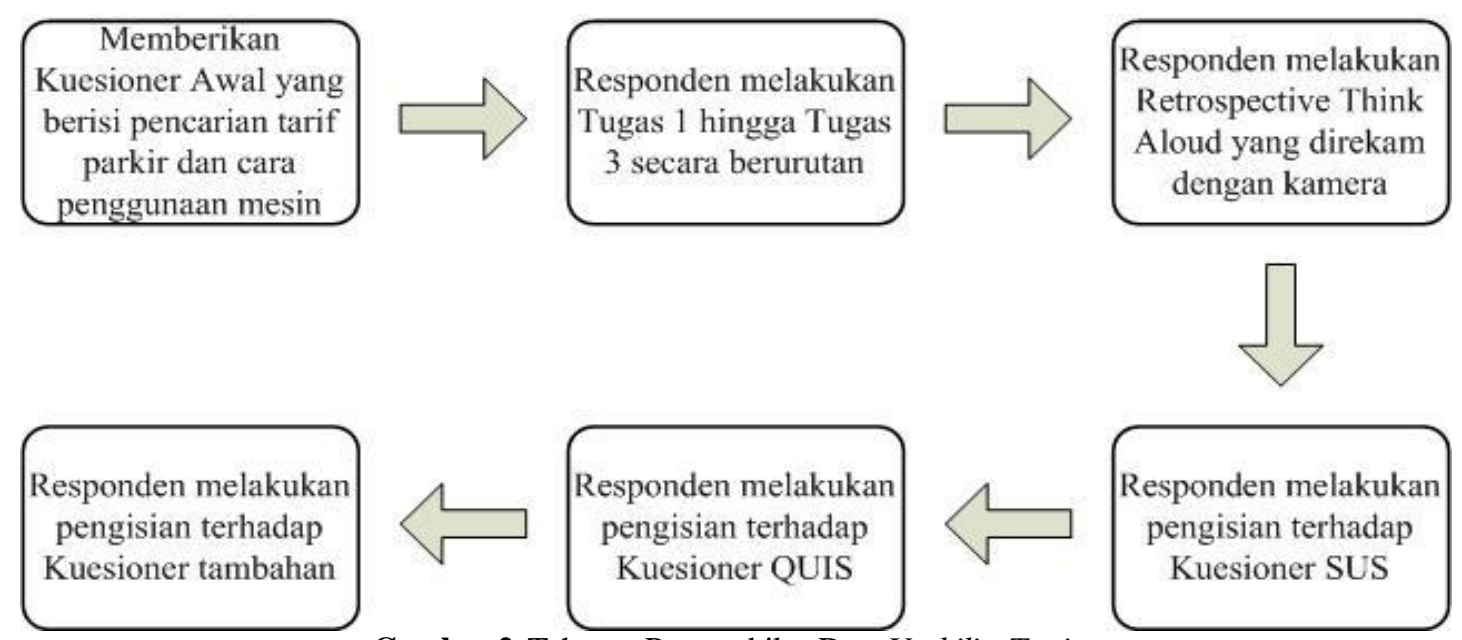

Gambar 2. Tahapan Pengambilan Data Usability Testing

Setelah melakukan usability testing maka langkah selanjutnya adalah perancangan ulang user interface mesin parkir meter Jakarta. Pada tahap ini data yang digunakan adalah data dari metode retrospective think aloud yang diolah kedalam pareto diagram. Adapun langkah - langkah dalam melakukan perancangan ulang user interface dapat dilihat pada gambar 3. Pada proses verifikasi pengujian desain baru user interface responden yang dilibatkan berjumlah 10 orang dan merupakan responden yang belum pernah menggunakan mesin parkir meter Jakarta. 


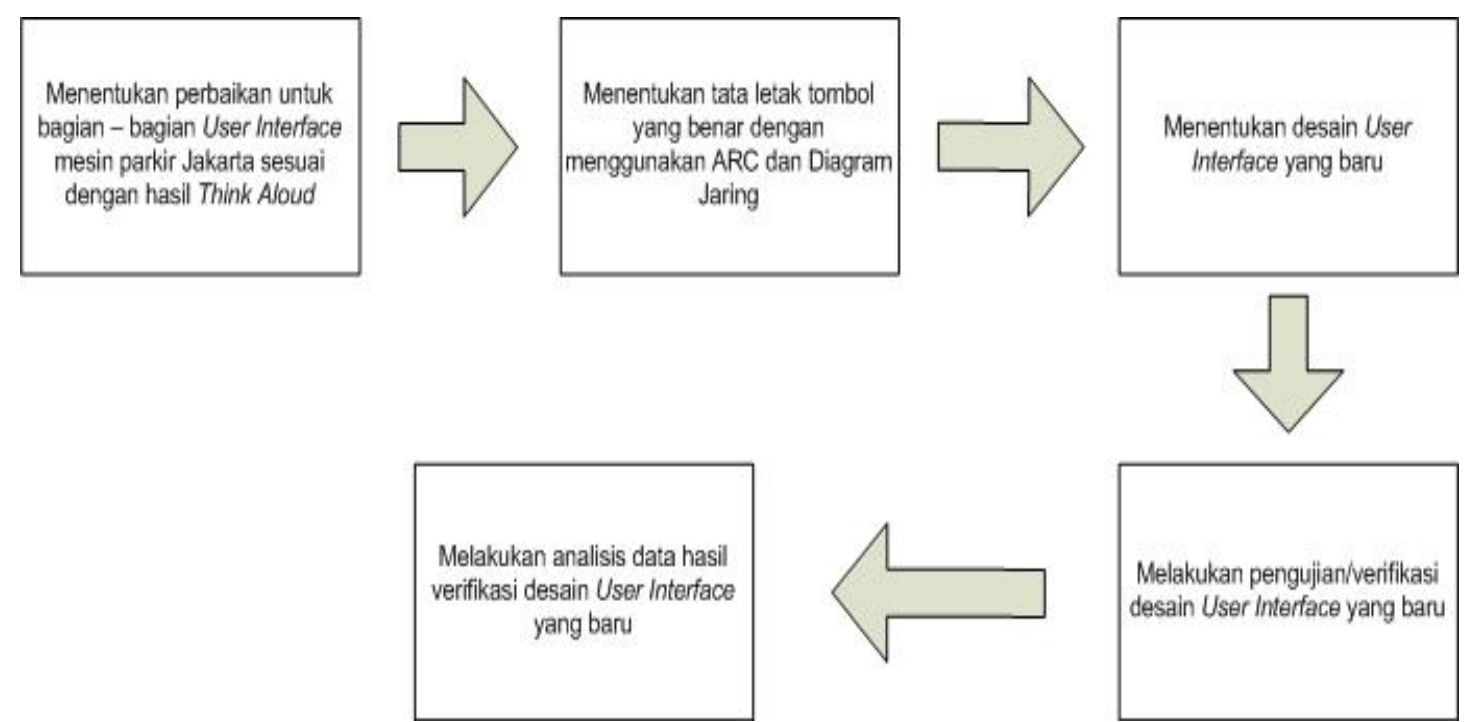

Gambar 3. Tahap Perancangan Ulang User Interface Mesin Parkir Meter

\section{Hasil dan Pembahasan}

\subsection{Hasil Usability Testing}

Pada pengolahan data usability testing ada beberapa pengolahan data yang dilakukan yaitu data performance measurement, data think aloud, data kuesioner SUS, dan data kuesioner QUIS. Untuk data performance measurement, dilakukan pengolahan data task time yang didapatkan untuk setiap tugas dengan uji t-test untuk melihat perbedaan antar kelompok responden, seperti tercantum pada tabel 1.

Tabel 1. Rangkuman Hasil uji t-test Kelompok Responden Mahir dan Pemula

\begin{tabular}{|c|c|c|}
\hline Uji t-test & P-value & Kesimpulan \\
\hline t-test kelompok mahir dan kelompok pemula untuk tugas 1 & 0,001 & Terdapat perbedaan signifikan \\
\hline t-test kelompok mahir dan kelompok pemula untuk tugas 2 & 0,000 & Terdapat perbedaan signifikan \\
\hline t-test kelompok mahir dan kelompok pemula untuk tugas 3 & 0,005 & Terdapat perbedaan signifikan \\
\hline
\end{tabular}

Dari hasil uji t-test didapatkan kesimpulan bahwa ada perbedaan yang signifikan pada data task time responden mahir dan responden pemula. Dimana hasil uji t-test menunjukkan p-value masih berada dibawah $\alpha=0,05$. Selanjutnya dilakukan pengolahan data untuk data think aloud dengan menggunakan segmentasi pada setiap komentar yang disebutkan oleh responden. Hasil pengolahan data think aloud dapat dilihat pada gambar 4. Pada gambar grafik dibawah ini dapat dilihat bahwa komentar negatif paling banyak terdapat pada segmen tombol yaitu mencapai hingga $52 \%$, selanjutnya $20 \%$ tentang layar dan $10 \%$ tentang keyboard. Hasil pengolahan data ini dapat digunakan untuk melakukan perancangan ulang user interface mesin parkir meter Jakarta.

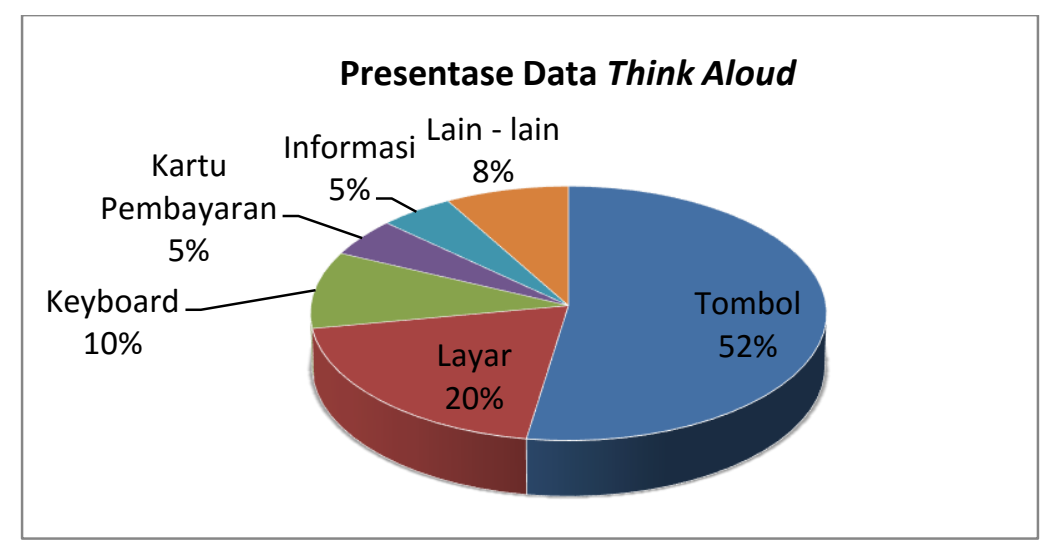

Gambar 4. Presentase Segmentasi Data Think Aloud 
Pengolahan data berikutnya adalah data dari kuesioner SUS. Pengolahan data dilakukan dengan membuat frekuensi distribusi SUS score seperti yang dapat dilihat pada gambar 5 dibawah ini.

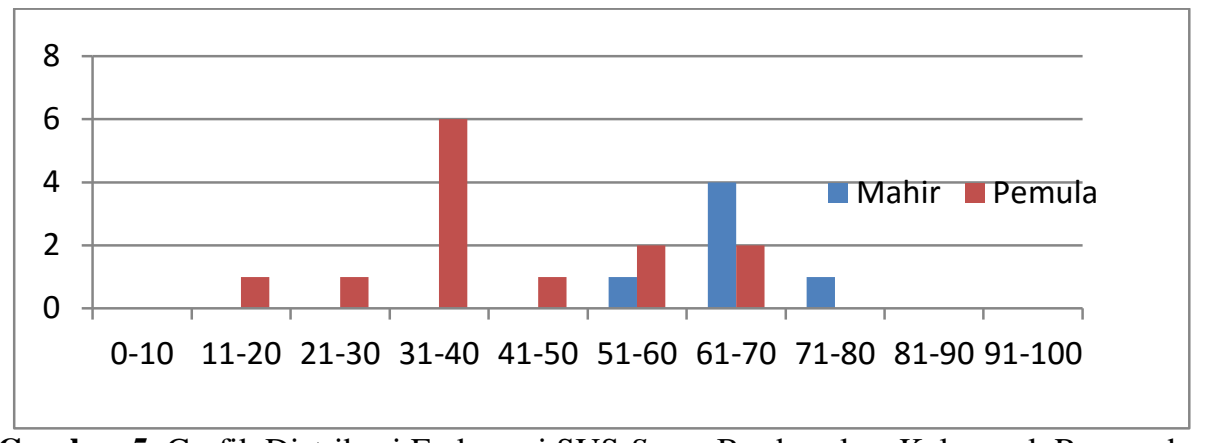

Gambar 5. Grafik Distribusi Frekuensi SUS Score Berdasarkan Kelompok Responden

Setelah melakukan pengolahan data dan uji t-test, maka dilakukan interpretasi nilai SUS seperti yang dapat dilihat pada gambar 5. Pada gambar interpretasi kotak biru adalah responden kelompok mahir dan kotak merah adalah responden kelompok pemula. Gambar 6 dibawah ini menunjukkan bahwa SUS score yang diberikan oleh kelompok pemula masih lebih rendah jika dibandingkan dengan kelompok mahir. Hal ini juga dapat dibuktikan dengan melakukan uji t-test terhadap SUS score kelompok mahir dan kelompok pemula. Data SUS score dari kelompok responden pemula yang digunakan dalam uji ini dipilih secara acak. Sebelum melakukan uji t-test, maka dilakukan uji normalitas terlebih dahulu dan hasil p-value pada probability plot uji normalitas untuk SUS score adalah 0,743 untuk kelompok mahir dan 0,086 untuk kelompok pemula. Hasil uji t-test SUS score menunjukkan p-value sebesar 0,04 yang menunjukkan perbedaan yang signifikan untuk SUS score pada kelompok mahir dan kelompok pemula.

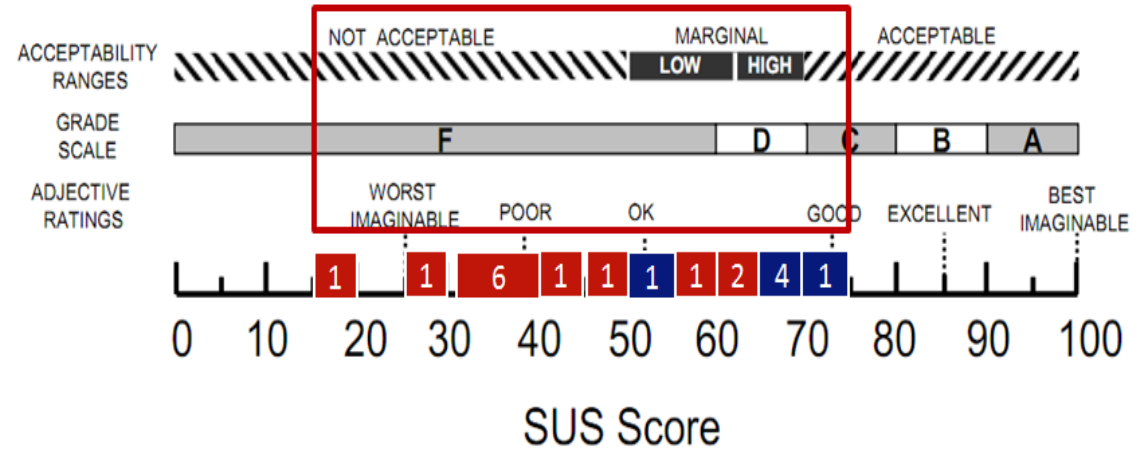

Gambar 6. Interpretasi SUS Score Mesin Parkir Meter Jakarta

Dalam interpretasi nilai kuesioner SUS diatas, dapat kita lihat bahwa nilai SUS untuk mesin parkir meter Jakarta masih ada yang dalam range nilai 15-70 (yang berada dalam kotak merah pada gambar). Dari penilaian adjective ratings dapat kita lihat bahwa nilai SUS mesin parkir meter Jakarta berada dalam range worst imaginable hingga good, dari penilaian grade scale dapat kita lihat bahwa nilai SUS mesin parkir meter Jakarta berada dalam range $\mathrm{F}$ hingga $\mathrm{C}$, dari penilaian acceptability ranges dapat kita lihat bahwa nilai SUS mesin parkir meter Jakarta berada dalam range not acceptable hingga marginal high dan awal acceptable.

\subsection{Pembahasan Usability Testing}

Hasil usability testing mesin parkir meter Jakarta menunjukkan bahwa mesin parkir meter Jakarta masih memiliki nilai usability yang rendah dimana dari kuesioner awal ditemukan fakta bahwa responden masih menemui kesulitan ketika mencari tarif parkir dan masih ada responden yang menemui kesulitan dalam membaca atau mengerti SOP yang telah ditempelkan pada bagian depan mesin. Hasil pengolahan data kuesioner SUS juga masih kurang memuaskan dimana SUS Score mesin parkir meter Jakarta masih berada dalam range worst imaginable dan dalam grade scale F hingga D. Dalam pengolahan data kuesioner QUIS juga masih terlihat ketidakefektifan user interface dimana masih terdapat mean yang cukup rendah untuk beberapa kategori pada user interface mesin yaitu kategori fungsi perintah dalam mesin dan kehandalan mesin yang dirasakan masih cukup rendah. Untuk teknik performance measurement, data menunjukkan bahwa dalam penggunaan mesin, pengalaman penggunaan mesin masih berpengaruh secara signifikan terhadap task time pada pengerjaan tugas 1 hingga tugas 3, dan masih banyaknya error yang dilakukan oleh responden kelompok pemula pada setiap tugas yang menjadi bukti bahwa usability mesin parkir meter masih rendah. 


\subsection{Perancangan Ulang User Interface Mesin Parkir Jakarta}

Data think aloud menunjukkan komentar yang cukup beragam dari para responden, dimana $82 \%$ responden memberikan komentar negatif tentang tombol, layar dan keyboard. Kuesioner tambahan yang diberikan kepada responden juga menunjukkan hasil dimana responden masih kurang puas secara keseluruhan terhadap mesin parkir meter. Dan responden cenderung Sangat Setuju terhadap "user interface mesin belum baik dan perlunya perancangan user interface baru untuk mesin parkir meter Jakarta". Selain itu komentar - komentar responden tentang kekurangan mesin juga akan menjadi panduan tambahan pada perancangan ulang desain user interface mesin parkir meter Jakarta.

Hasil pengolahan data Think Aloud akan disajikan dalam bentuk Pareto Diagram untuk melihat bagian - bagian yang paling berpengaruh untuk perbaikan user interface mesin. Pareto diagram untuk data Think Aloud responden dapat dilihat pada gambar 7. Dari gambar pareto diagram dibawah ini dapat dilihat bahwa dengan melakukan penyelesaian pada masalah - masalah tombol, layar dan keyboard akan menyelesaikan $80 \%$ masalah pada usability mesin parkir meter Jakarta.

\section{Pareto Diagram untuk Data Think Aloud}

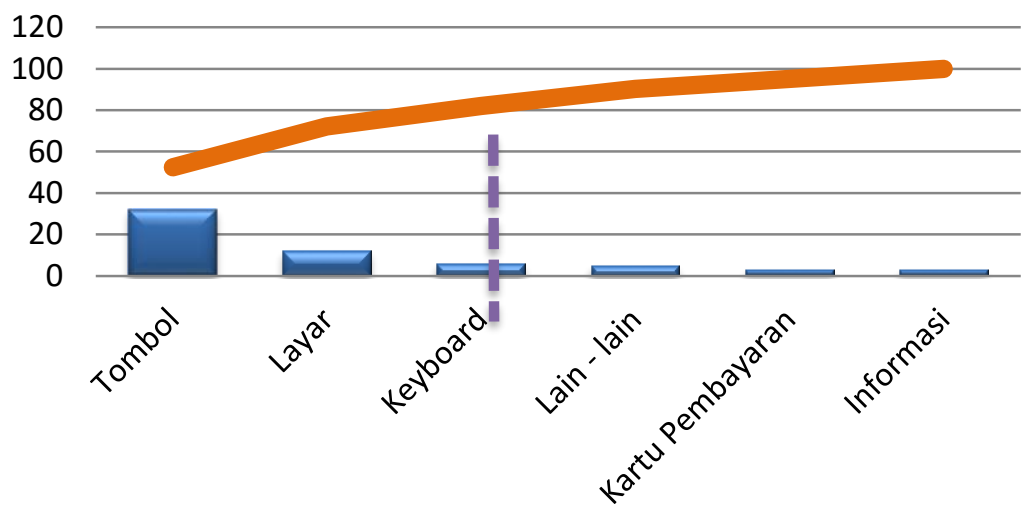

Gambar 7. Pareto Diagram untuk Data Think Aloud

Dalam pengaturan tata letak bagian - bagian pada user interface mesin, maka dilakukan dengan membuat Activity Relationship Chart (ARC). Untuk pembuatan ARC mesin parkir meter Jakarta akan dipermudah dengan membuat clustering dimana tombol untuk pilihan jenis kendaraan akan dijadikan dalam satu bagian, begitu juga dengan tombol konfirmasi yes, no dan back. Alternatif pilihan mesin parkir meter Jakarta dapat dilihat pada gambar 8 .
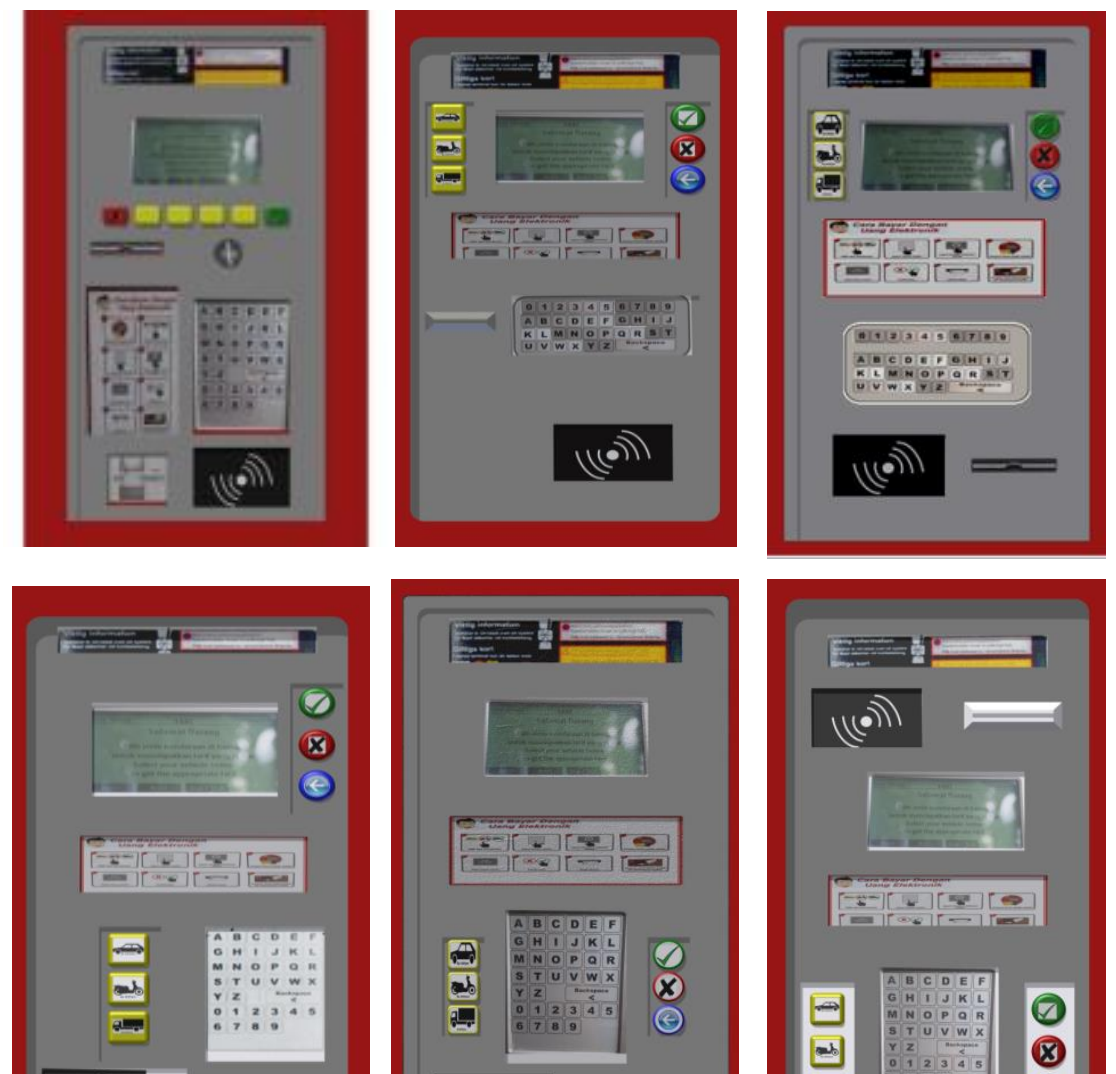
Gambar 8. Alternatif Pilihan Desain Mesin Parkir Meter

Keterangan: Kiri atas ke kanan bawah: desain awal, kombinasi 1, kombinasi 2, kombinasi 3, kombinasi 4, dan kombinasi 5

Setelah melakukan desain user interface berdasarkan pilihan diagram jaring, kemudian dibuat kuesioner untuk mengetahui preferensi subjektif tentang perubahan yang telah dilakukan dan pemilihan desain user interface yang paling efektif dan efisien. Kuesioner preferensi subjektif diisi oleh 237 responden dengan hasil $83 \%$ responden yang mengisi kuesioner preferensi subjektif memilih SOP baru yang lebih efektif untuk digunakan pada mesin parkir meter Jakarta. Pada bagian perubahan keyboard, 82\% responden memilih jenis keyboard baru yang akan lebih efektif untuk digunakan pada desain user interface yang baru. Dan untuk tombol pilihan jenis kendaraan, $81 \%$ responden memilih tombol pilihan kendaraan jenis kedua yaitu tombol kuning dengan gambar kendaraan yang akan dipilih oleh pengguna. Pada pilihan desain user interface, responden dominan memilih Kombinasi 2.

Selanjutnya dilakukan proses verifikasi pada hasil rancangan ulang user interface Kombinasi 2. Responden dalam proses verifikasi ini hanya responden kelompok pemula untuk menilai usability dari hasil perancangan ulang. Dalam pengambilan data verifikasi, disimulasikan pemakaian mesin. Dan dalam pengambilan data, desain lama juga turut disimulasikan untuk melihat perbedaan waktu pengerjaan responden dengan simulasi desain lama dan simulasi desain baru. Untuk tugas yang diberikan kepada responden masih sama dengan tugas pada pengambilan data yang dilakukan pada bab sebelumnya. Dalam pengambilan data verifikasi ini, pemberian jenis tugas dan desain dilakukan secara acak. Dan kuesioner SUS juga digunakan untuk menilai usability pada simulasi desain baru (Pilihan 2) dan simulasi desain lama mesin parkir. Pada tahap verifikasi, data yang didapatkan adalah data task time dan nilai SUS, rangkuman uji t-test data task time verifikasi dapat dilihat pada tabel 2 dibawah ini.

Tabel 2. Hasil Uji T-test data task time

\begin{tabular}{|c|c|c|}
\hline Uji t-test & P-value & Kesimpulan \\
\hline$t$-test simulasi desain lama dan simulasi desain baru untuk tugas 1 & 0,002 & Ada perbedaan \\
\hline$t$-test simulasi desain lama dan simulasi desain baru untuk tugas 2 & 0,000 & Ada perbedaan \\
\hline$t$-test simulasi desain lama dan simulasi desain baru untuk tugas 3 & 0,000 & Ada perbedaan \\
\hline
\end{tabular}

Hasil uji normalitas pada data task time verifikasi desain kombinasi 2 menunjukkan data terdistribusi normal dan hasil uji t-test menunjukkan p-value yang lebih kecil dari 0,05. Hasil ini menunjukkan ada perbedaan yang sangat signifikan pada task time verifikasi dengan menggunakan simulasi desain lama dan simulasi desain baru. Hal ini membuktikan bahwa desain baru lebih efisien dan efektif daripada desain lama. Selain itu, distribusi frekuensi SUS score menunjukkan hasil bahwa nilai SUS simulasi desain baru berada dalam range 51-100 sementara nilai SUS untuk desain lama masih berada dalam range 11-50. Pada desain baru terdapat rata - rata nilai SUS sebesar 73,8 sedangkan untuk desain lama terdapat rata - rata sebesar 34. Selanjutnya dilakukan uji t-test untuk melihat perbedaan SUS score yang diberikan oleh responden terhadap desain lama dan desain baru. Rangkuman hasil uji uji t-test SUS score dapat dilihat pada 9 dibawah ini.

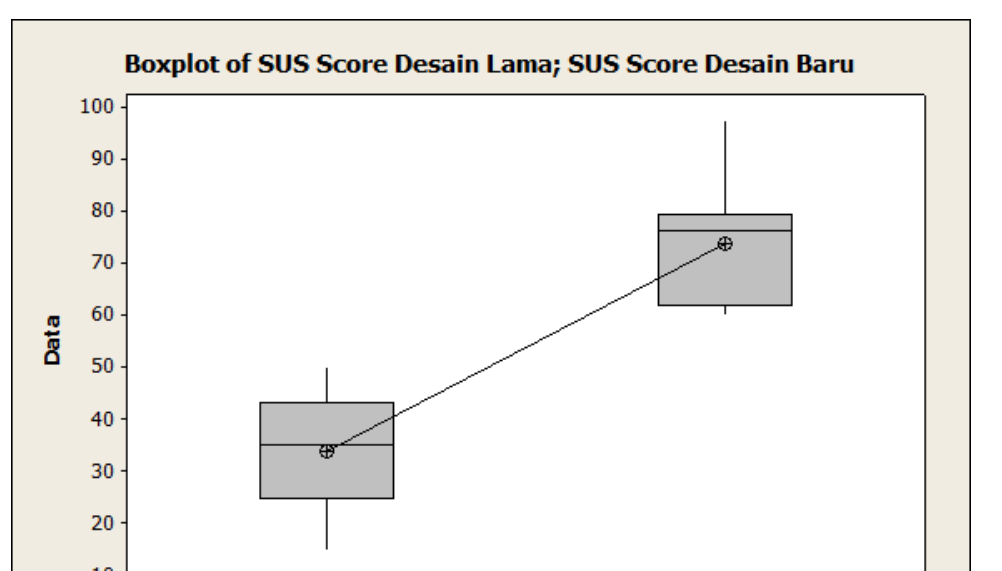




\section{Gambar 9. Hasil Uji Boxplot SUS Desain Lama dan Desain Baru}

P-value yang didapatkan pada uji t-test ini adalah 0,000 dimana hal ini membuktikan bahwa ada perbedaan signifikan pada SUS score untuk simulasi desain lama dan simulasi desain baru. Pada data verifikasi diatas, terdapat beberapa hasil yang menunjukkan bahwa desain baru (Pilihan 2) lebih efektif jika dibandingkan dengan desain lama. Pengerjaan setiap tugas dengan simulasi desain user interface yang baru terbukti lebih cepat dibandingkan dengan pengerjaan menggunakan simulasi desain lama. Pada hasil uji t-test dapat dilihat bahwa pvalue yang dihasilkan membuktikan terdapat perbedaan yang sangat signifikan pada task time untuk tugas 1,2 dan 3. Dari hasil task time pada verifikasi menunjukkan bahwa desain baru lebih efisien daripada desain lama dan hal ini terbukti berbeda secara signifikan. Hasil yang sama juga ditunjukkan pada pengolahan data nilai SUS dimana semua responden memberikan nilai SUS yang lebih tinggi untuk simulasi desain baru. Hasil uji t-test menunjukkan p-value sebesar 0,000 dan ini membuktikan ada perbedaan yang sangat signifikan untuk SUS score yang pada simulasi desain lama dan simulasi desain baru.

\section{Kesimpulan dan Saran}

Kesimpulan yang terdapat pada penelitian ini terbagi menjadi dua bagian. Pertama, tingkat usability mesin parkir meter Jakarta masih rendah, dimana nilai kuesioner SUS untuk mesin ini masih berada dalam range worst imaginable hingga poor dan masih dalam grade scale F hingga D. Selanjutnya pada pengolahan data task time terlihat bahwa waktu pengerjaan yang dibutuhkan oleh kelompok responden pemula berbeda signifikan dengan waktu pengerjaan pada kelompok responden mahir. Hal ini membuktikan bahwa usability mesin masih rendah dimana terdapat pengaruh pengalaman terhadap task time secara signifikan. Hasil berikutnya adalah banyaknya error yang masih dilakukan oleh responden ketika melakukan tugas dengan mesin dan masih banyak kekurangan mesin yang dirasakan oleh pengguna.

Kedua, hasil dari metode think aloud menunjukkan bahwa masalah yang paling sering ditemui responden atau pengguna ketika melakukan transaksi dengan mesin parkir meter terletak pada tombol, layar dan keyboard. Activity Relationship Chart (ARC) digunakan untuk melakukan perancangan ulang user interface. Selanjutnya, rancangan ulang user terbukti lebih efektif daripada desain lama. Hasil dari penelitian ini menunjukkan bahwa desain user interface kombinasi 2 lebih efektif untuk mesin parkir meter Jakarta.

\section{Daftar Pustaka}

[1] Kementerian Perhubungan Republik Indonesia. (1994). Keputusan Menteri Perhubungan Nomor : KM.4 Tahun 1994 tentang Tata Cara Parkir Kendaraan Bermotor di Jalan. Jakarta: Menteri Perhubungan Republik Indonesia.

[2] Susdiyono. (2003). Kajian Pendapatan Daerah Propinsi DKI Jakarta Melalui Retribusi Parkir (Menuju Pelaksanaan Pajak Parkir). Jakarta: Universitas Indonesia.

[3] Seffah, A., \& Metzker, E. (2004). The obstacles and myths of usability and software engineering. Communications of the ACM, 71-76.

[4] Jaspers, M. W., Steen, T., Bos, C. v., \& Geenen, M. (2004). The think aloud method : a guide to user interface design. International Journal of Medical Informatics 73, 781-795.

[5] Wilbert O. Galitz. (2002). The Essential Guide to User Interface Design. Canada: John Wiley \& Sons, Inc. 
